\title{
Education and Development of Muslims in India: A Comparative Study
}

\author{
${ }^{1}$ Dr. Jabir Hasan Khan, ${ }^{2}$ Dr. Falak Butool, \\ Associate Prof, Deptt of Geography, Aligarh Muslim University, Aligarh, U.P, India \\ Post Doctoral Fellow, Deptt of Geography, Aligarh Muslim University, Aligarh, U.P., India
}

\begin{abstract}
The present paper aims to analyse the state wise educational status of Muslims in India. It also aims to compare the educational status of muslims with the educational status of other religious communities in India. The country level and state level published data have been obtained from census of India. At the same time the association between the educational status of muslims is sought with their socio-economic development. The results have revealed that the educational status of Muslims in India is not satisfactory and needs special attention. It is found that more than half i.e., 53.95 per cent of the total population of the Muslims in India is illiterate with 17.48 per cent literate people just for the name sake only. Technical education or higher education is meager among the muslims. From the results it is also clear that Muslims who accounts for 13.46 per cent of the total population of the nation show lowest literacy rate, lowest percentage of higher education and lowest degree of female education. Budhist who only claim for less than half per cent of the total population of the country are most literate. The percentage of higher education, sex ratio and female literacy rate is also highest in this religious community.
\end{abstract}

Keywords Education, Development, Muslims, Religious Communities

\section{Introduction}

Muslims, the largest minority community in the country, constituting 13.4 per cent of the population, are seriously lagging behind in terms of most of the human development indicators. While the perception of deprivation is widespread among muslims, there has been no systematic effort since independence to analyse the condition of religious minorities in the country (Sachar Committee Report, 2006). Today, globally Muslims show the lowest literacy rate. http://www.islamfortoday.com/syed07.htm. A study, conducted by a committee comprising of the former pro-vice-chancellor of Aligarh Muslim University, K M Bahavuddin, among others, says, "We started with the impression that the situation of Muslims is comparatively better [in Kerala] but after collecting the data, we have come to the conclusion that their situation in Kerala has also been deteriorating in the last 20 years". http://www.indiatogather.org/2007/aur/edu-muslimedu.htm. Studies on human cognitive development have established that literacy enhances the critical faculties of individuals and enables them to reflect on the existential reality in which they have been placed (Katiyar, 2008). Education not only provides profound knowledge and expertise but is supposed to play a broad spectrum role in developing social, cultural and moral values in an individual. It gives right direction to desires, emotions and outward behavior of individuals which reflects in the total personality (Dayal, 2008). Education is a vital factor in the social transformation of a society and its economic amelioration (Sachchidananda, 1977). Thus education of any community with no exception to Muslims will not only be helpful for their development but also for the development of the whole nation. Human capital theory suggests that just as a physical capital (machines) augments a person's economic productivity, so human capital acquired through education improves the productivity of individuals. Studies on the Sources of economic growth demonstrate persuasively that education plays a major role as a factor in rise of output per worker.

Most of the studies on educational status have been attempted with references to literacy by sex and residence. Gosal (1979); Mathur (1988); Gupta and Kothari (1990); Tripathi (1993). The growth and spread of literacy level, its distribution, causes and historical consequences have been studied in context of demographic, social and economic situation of Uttar Pradesh (Siddiqui, 1977 and Singh, 1979). Some of the studies also dealt with such correlates as working population and the results of these were found to be inversely related to each other (Acharya, 1984; Singh, 1986 and Tripathi, 1993). The educational disparity in India is linked with socioeconomic conditions (Raza and Aggarwal, 1986; Nuna, 1989 and Pcione, 1997). The interstate disparities in educational development in India have been analysed by Tilak (1979), Redy (1985), Zaidi (1986), Mehta (1990) and Malhotra (1999). The study of inter-district inequalities in terms of literacy and educational development has been attempted by Saradamoni (1981) and Dash (1993). Educational attainment by gender has done by Doughal (2000). The relationship between education and work participation has been analysed by Siddiqui and Naseer (2004). The relationship between education and regional economic development has been examined by 
Dube and Mishra (1981), Chaudhary and Nair (1981) and Singh (1979). But perhaps there is no such macro level study which deals with the comparative study of educational status of Muslims in India. Therefore, in this paper an attempt has been made to visualize the educational status of Muslims and its relationship with their socio-economic development, taking India as a case study and state as a unit of analysis.

\section{Objectives}

The major objectives of this research paper are: analysing the state wise educational status of the Muslims in India; comparing the educational status of muslims with the educational status of other religious communities and to find out the relationship between the educational status of muslims with their socioeconomic development.

\section{Data Base And Methodology}

The entire study is based upon the secondary sources of data which have been collected from Census of India publications, New Delhi for the year 2001. Simple percentage method has been used for calculating educational status. Apart from it multiple correlation technique and student t- test is used to find out relationship between educational status of muslims with their socio-economic development, whereas, GIS Arc Veiw is used for making concerned maps.

\section{Study Area}

India is lying between $8^{\circ} 4^{\prime}$ and $37^{\circ} 6^{\prime}$ North latitudes and $68^{\circ} 7^{\prime}$ and $97^{\circ} 25^{\prime}$ East longitudes. It is bounded by Pakistan and Afganistan in the North West, China, Nepal and Bhutan in the north, Mayanmar and Bangladesh in the east. It covers an area of $32,87,263 \mathrm{Km}^{2}$. India is the seventh largest country in terms of area, while in terms of population it ranks second. According to 2001 census, the country has been divided into twenty eight states and seven union territories.

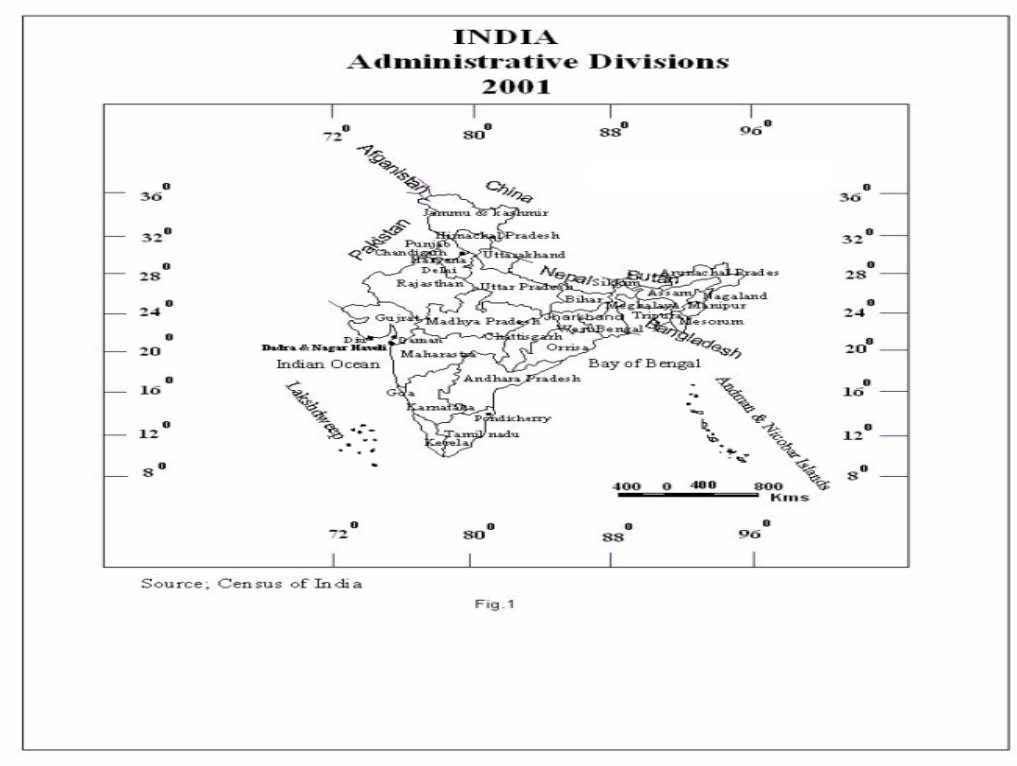

\section{V.1 Educational status of Muslims in India}

\section{Discussion}

The new growth theories in Economics place education and human resource development at the centre of their explanation for long term economic growth. Education is not just a social amenity; it is the foundation of socio-economic development of a country. 
Education and Development of Muslims in India: A Comparative Study

Table 1: State wise Educational status Among the Muslims, India, 2001

\begin{tabular}{|c|c|c|c|c|c|c|c|}
\hline $\begin{array}{l}\text { Administrative } \\
\text { Divisions }\end{array}$ & $\begin{array}{c}\text { Unclassified } \\
\text { Literates }\end{array}$ & $\begin{array}{l}\text { Primary } \\
\text { Literates }\end{array}$ & $\begin{array}{c}\text { Secondary } \\
\text { Literates }\end{array}$ & $\begin{array}{l}\text { Technical } \\
\text { and Non } \\
\text { technical } \\
\text { Diploma } \\
\text { Holders }\end{array}$ & $\begin{array}{l}\text { Graduates } \\
\text { and above }\end{array}$ & $\begin{array}{l}\text { Literacy } \\
\text { Rate }\end{array}$ & $\begin{array}{c}\text { Percentage } \\
\text { of } \\
\text { Muslims } \\
\text { to total } \\
\text { Population }\end{array}$ \\
\hline INDIA & 17.489 & 21.187 & 7.446 & 0.198 & 1.728 & 48.05 & 13.43 \\
\hline $\begin{array}{l}\text { Jammu \& } \\
\text { kashmir }\end{array}$ & 10.93 & 16.985 & 9.496 & 0.039 & 2.558 & 40.01 & 66.97 \\
\hline $\begin{array}{l}\text { Himachal } \\
\text { Pradesh }\end{array}$ & 15.46 & 22.776 & 8.555 & 0.2 & 1.253 & 48.24 & 1.97 \\
\hline Punjab & 13.156 & 20.196 & 8.28 & 0.107 & 1.112 & 42.85 & 1.57 \\
\hline Chandigarh & 14.409 & 26.243 & 9.714 & 0.141 & 2.625 & 53.13 & 3.95 \\
\hline Uttarakhand & 17.408 & 16.943 & 4.54 & 0.113 & 1.279 & 40.28 & 11.92 \\
\hline Haryana & 14.129 & 12.368 & 3.107 & 0.131 & 0.425 & 30.16 & 5.78 \\
\hline Delhi & 15.357 & 25.256 & 9.912 & 0.144 & 3.609 & 54.28 & 11.72 \\
\hline Rajasthan & 20.053 & 19.012 & 4.503 & 0.054 & 1.112 & 44.73 & 8.47 \\
\hline Uttar Pradesh & 15.229 & 16.146 & 4.996 & 0.088 & 1.355 & 37.81 & 18.5 \\
\hline Bihar & 13.741 & 12.91 & 4.471 & 0.151 & 1.479 & 32.75 & 16.53 \\
\hline Sikkim & 19.602 & 21.422 & 7.006 & 0.182 & 1.963 & 50.18 & 1.42 \\
\hline $\begin{array}{l}\text { Arunachal } \\
\text { Pradesh }\end{array}$ & 13.852 & 21.2 & 9.412 & 0.276 & 2.162 & 46.90 & 1.88 \\
\hline Nagaland & 10.887 & 19.177 & 7.553 & 0.074 & 1.277 & 38.97 & 1.76 \\
\hline Manipur & 11.536 & 22.535 & 9.745 & 0.045 & 3.069 & 46.93 & 8.81 \\
\hline Mizoram & 28.28 & 31.152 & 6.09 & 0.188 & 1.485 & 67.19 & 1.14 \\
\hline Tripura & 24.953 & 20.962 & 2.682 & 0.022 & 0.89 & 49.51 & 7.95 \\
\hline Meghalaya & 13.06 & 12.824 & 6.306 & 0.066 & 1.392 & 33.65 & 4.28 \\
\hline Assam & 15.961 & 15.108 & 5.646 & 0.055 & 1.093 & 37.86 & 30.92 \\
\hline West Bengal & 23.711 & 18.248 & 3.768 & 0.029 & 0.964 & 46.72 & 25.25 \\
\hline Jharkhand & 17.382 & 17.903 & 6.62 & 0.122 & 1.779 & 43.81 & 13.85 \\
\hline Orrisa & 18.18 & 28.193 & 10.411 & 0.426 & 2.332 & 59.54 & 2.07 \\
\hline Chattisgarh & 19.378 & 31.163 & 13.98 & 0.347 & 4.852 & 69.72 & 1.97 \\
\hline Madhya Pradesh & 20.334 & 26.258 & 8.396 & 0.105 & 2.654 & 57.75 & 6.37 \\
\hline Gujrat & 19.049 & 30.595 & 10.357 & 0.313 & 1.584 & 61.90 & 9.06 \\
\hline Daman \& Diu & 16.815 & 32.733 & 17.572 & 0.586 & 2.752 & 70.46 & 7.76 \\
\hline $\begin{array}{l}\text { Dadra \& Nagar } \\
\text { Haveli }\end{array}$ & 16.999 & 32.434 & 14.117 & 1.15 & 2.759 & 67.46 & 2.96 \\
\hline Maharastra & 19.809 & 30.014 & 12.745 & 0.231 & 2.635 & 65.43 & 10.6 \\
\hline Andhra Pradesh & 15.29 & 24.462 & 14.27 & 0.463 & 3.397 & 57.88 & 9.17 \\
\hline Karnataka & 18.148 & 26.58 & 11.132 & 0.689 & 2.237 & 58.79 & 12.23 \\
\hline Goa & 17.511 & 27.628 & 15.431 & 0.54 & 2.81 & 63.92 & 6.84 \\
\hline Lakshdweep & 25.151 & 36.406 & 8.83 & 1.204 & 1.164 & 72.75 & 95.47 \\
\hline Kerela & 19.311 & 41.641 & 12.676 & 0.716 & 1.628 & 75.97 & 24.7 \\
\hline Tamilnadu & 18.409 & 36.65 & 13.87 & 0.509 & 2.732 & 72.17 & 5.56 \\
\hline Pondicherry & 12.906 & 41.167 & 17.376 & 0.824 & 4.042 & 76.31 & 6.09 \\
\hline $\begin{array}{l}\text { Andman \& } \\
\text { Nicobar }\end{array}$ & 14.044 & 39.446 & 20.297 & 0.94 & 4.941 & 79.67 & 8.22 \\
\hline
\end{tabular}

Source; Census of India, Tab C-9, 2001

Ensuring quality school education to all is the foundation upon which any further advances towards a knowledge society must be based. http://www.knowledgecommission.gov.in/recommendations/school.asp.

Thus, the importance of education cannot be denied when socio-economic development of any region is talked about. The present paper aimed at analyzing the educational status of Muslims in India (as one of its objectives). It was observed that more than half of the total Muslim Indian Population i.e., 53.95 per cent is illiterate with 17.48 per cent literate people just for the name sake only. Apart from it, 21.18 per cent people have completed their primary education only, whereas, the percent share of secondary literates among the Muslims is only 7.44 per cent. The Muslims with technical and non technical diploma courses are only 0.19 per cent and in the higher studies their share is only 1.728 per cent. (Tab 1). It can also be visualizedfrom the tab 1 that Muslim's literacy rate is highest (79.67 per cent) in Andman and Nicobar Island but they constitute only 8.22 percent of the total Population. The states with comparatively larger share of Muslims in higher education are namely, Andman and Nicobar. Apart from it majority of the muslim literate people are either literate without any educational level (17.49 per cent) or they are primary literates (21.19 per cent). Technical education or higher education is meager among the muslim. Here one thing is clear that per cent share of Muslims in higher education is more, mainly in the least developed tribal areas, whereas, technical education among the Muslims is higher is the southern states. 


\section{V.II Distributional Patterns of Literacy among the Muslims in India, 2001}

It is revealed from the fig 2 that muslim literacy rate varies from 75.97 per cent in Kerela to 30.16 per cent in the state of Haryana in 2001. The whole range is divided into five groups. These groups along with their numerical values are as follows: Very High (70 per cent and above), High ( 60 per cent to 69.99 per cent), Medium ( 50 per cent to 59.99 per cent), Low (40 per cent to 49.99 per cent) and Very Low (below 40 per cent). The very high literacy rate of muslims is observed only in the two southern states namely, Kerela and Tamilnadu. The category of high level of literacy rate of muslims is occupied by the states of Gujrat, Maharastra, Goa, Chattisgarh and Tripura. Medium level of literacy is recorded in Madhya Pradesh, Orrisa, Andhra Pradesh, and Karnataka. Low level of literacy is observed mainly in the upper hilly States of Jammu and Kashmir, Himachal Pradesh, Punjab, Uttarakhand and one arid state. However, the other states of the same category are Rajasthan, Jharkhand, West Bengal, Sikkim, Arunachal Pradesh, Mesoram and Manipur. Very low level of literacy among the muslims is observed in the form of a belt running from west to east covering the states of Haryana, Uttar Pradesh, Bihar, Meghalaya, Assam and Nagaland.

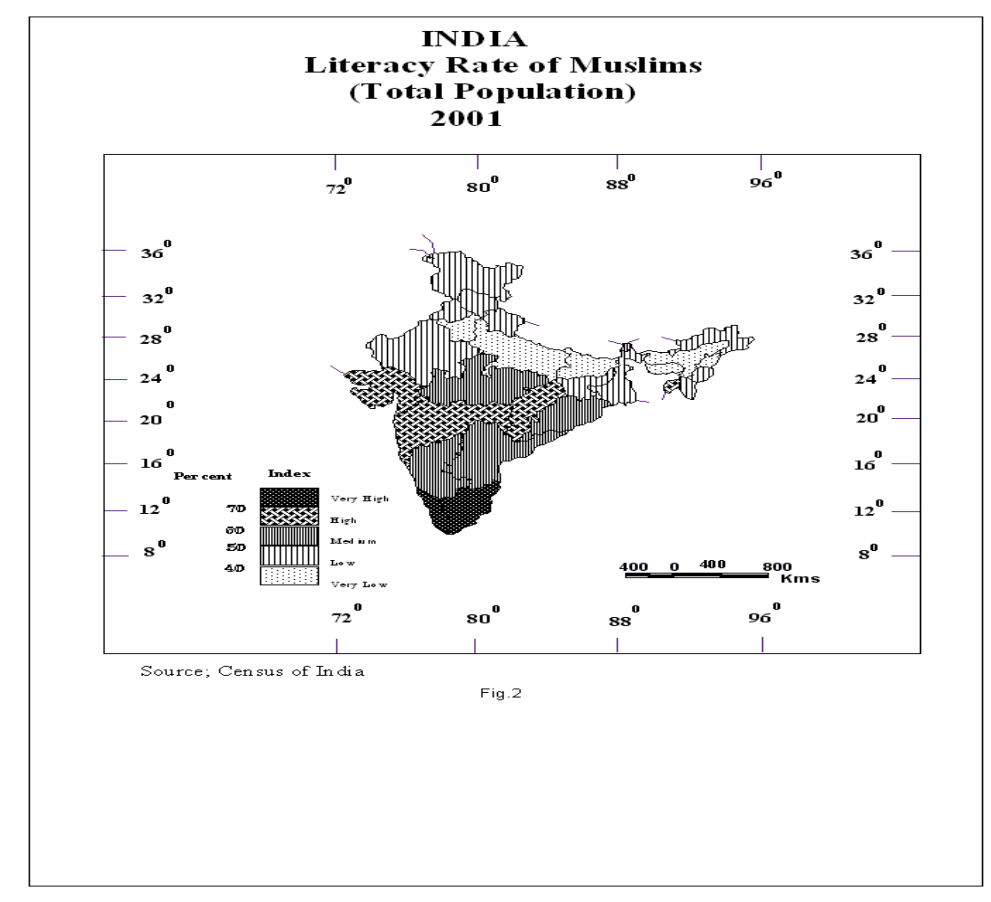

Tab 2: Educational Status of Muslims in Relation to Other Religious Communities

\begin{tabular}{|c|c|c|c|c|c|c|c|c|c|c|}
\hline $\begin{array}{l}\text { Religious } \\
\text { Groups }\end{array}$ & $\begin{array}{l}\text { Per cent of } \\
\text { total } \\
\text { population }\end{array}$ & $\begin{array}{l}\text { Literacy } \\
\text { Rate }\end{array}$ & $\begin{array}{l}\text { Below } \\
\text { Primary } \\
\text { Literacy } \\
\text { Rate }\end{array}$ & $\begin{array}{l}\text { Primary } \\
\text { Literacy } \\
\text { Rate }\end{array}$ & $\begin{array}{l}\text { Secondary } \\
\text { Literacy } \\
\text { Rate } \\
\end{array}$ & $\begin{array}{l}\text { Technical } \\
\text { and non } \\
\text { Technical } \\
\text { Diploma } \\
\text { holders }\end{array}$ & $\begin{array}{l}\text { Graduates } \\
\text { and above }\end{array}$ & $\begin{array}{l}\text { Sex } \\
\text { Ratio }\end{array}$ & $\begin{array}{l}\text { Male } \\
\text { Literacy } \\
\text { Rate }\end{array}$ & $\begin{array}{l}\text { Female } \\
\text { Literacy } \\
\text { Rate }\end{array}$ \\
\hline & 100.00 & 54.51 & 16.04 & 23.04 & 11.38 & 0.39 & 3.66 & 932 & 63.24 & 45.15 \\
\hline Hindu & 80.46 & 54.92 & 15.88 & 23.16 & 11.63 & 0.39 & 3.85 & 930 & 64.22 & 44.92 \\
\hline Muslim & 13.43 & 48.05 & 17.49 & 21.19 & 7.45 & 0.20 & 1.73 & 936 & 54.99 & 40.63 \\
\hline Christian & 2.34 & 69.45 & 16.14 & 27.56 & 18.18 & 1.52 & 6.05 & 1009 & 72.76 & 66.17 \\
\hline Sikh & 1.87 & 60.56 & 12.53 & 26.01 & 17.27 & 0.54 & 4.20 & 892 & 65.03 & 55.56 \\
\hline Budhist & 0.77 & 62.16 & 18.60 & 26.29 & 13.52 & 0.22 & 3.54 & 952 & 71.05 & 52.83 \\
\hline Jain & 0.41 & 84.09 & 11.51 & 23.64 & 30.03 & 0.87 & 18.05 & 940 & 86.67 & 81.35 \\
\hline $\begin{array}{l}\text { Other } \\
\text { Religions }\end{array}$ & 0.65 & 38.57 & 13.80 & 16.91 & 6.09 & 0.10 & 1.68 & 992.36 & 49.78 & 27.27 \\
\hline
\end{tabular}

Source; Census of India, Tab: C9, 2001

From the above table it is clear that more than eighty per cent of the total population belongs to Hindu community. Muslims accounts for 13.43 per cent of the total population whereas, a little less than ten per cent of the total population is constituted by Christian, Sikh, Budhist, Jain and other religious communities. Literacy rate is highest (84.09 per cent) among the jains who only accounts for less than half per cent of the total population; Christian occupies the second position followed by Budhist, Sikh, Hindu and the last Muslims in this order. A detailed analysis of the concerned table shows that below primary literacy rate is highest among the muslims and secondary, technical and higher education is lowest among the muslims. Apart from it male female 
literacy gap is also highest among the muslims. While analyzing the sex ratio, it is found that muslims lie that second last position they come only after Hindus; and Christians occupies the top most position as far as sex ratio is concerned.

\section{V.III Educational Status and socio-economic development of Muslims in India, 2001}

In the present investigation a relationship has been sought between educational status and socioeconomic development of muslims in India. This is done to obtain a rational hypothesis of relationship between the

Table 3: Results of Correlation (r) Between Educational Status of Muslims and Other Selected Variables of their Socio-economic Development, India, 2001

\begin{tabular}{|c|c|c|c|c|c|c|}
\hline $\begin{array}{l}\text { Variabl } \\
\text { es }\end{array}$ & Definition & $\begin{array}{l}\text { Per } \\
\text { cent } \\
\text { of } \\
\text { Uncla } \\
\text { ssified } \\
\text { Musli } \\
\text { m } \\
\text { Litera } \\
\text { tes } \\
\left(\mathrm{Y}_{1}\right)\end{array}$ & $\begin{array}{l}\text { Per } \\
\text { cent } \\
\text { of } \\
\text { Prima } \\
\text { ry } \\
\text { Musli } \\
\text { m } \\
\text { Litera } \\
\text { tes } \\
\left(\mathrm{Y}_{2}\right)\end{array}$ & $\begin{array}{l}\text { Per } \\
\text { cent } \\
\text { of } \\
\text { Secon } \\
\text { dary } \\
\text { Musli } \\
\text { m } \\
\text { Litera } \\
\text { tes } \\
\left(\mathrm{Y}_{3}\right)\end{array}$ & $\begin{array}{l}\text { Per } \\
\text { cent of } \\
\text { Musli } \\
\mathrm{m} \\
\text { Techni } \\
\text { cal and } \\
\text { Non } \\
\text { Techni } \\
\text { cal } \\
\text { Diplo } \\
\text { ma } \\
\text { Holder } \\
\text { s }\left(Y_{4}\right)\end{array}$ & $\begin{array}{l}\text { Per } \\
\text { cent } \\
\text { of } \\
\text { Musl } \\
\text { im } \\
\text { Grad } \\
\text { uates } \\
\text { and } \\
\text { Abov } \\
\text { e } \\
\left(\mathrm{Y}_{5}\right)\end{array}$ \\
\hline $\mathrm{X}_{1}$ & $\begin{array}{l}\text { Literacy Rate of Muslim } \\
\text { Population }\end{array}$ & .168 & .198 & -.066 & -.135 & $\begin{array}{l}- \\
\\
*\end{array}$ \\
\hline $\mathrm{X}_{2}$ & $\begin{array}{l}\text { Male Literacy Rate of } \\
\text { Muslim Population }\end{array}$ & -.070 & .107 & $\begin{array}{r}- \\
480^{*} \\
*\end{array}$ & -.181 & $\begin{array}{r}- \\
.428^{*} \\
*\end{array}$ \\
\hline $\mathrm{X}_{3}$ & $\begin{array}{l}\text { Female Literacy Rate of } \\
\text { Muslim Population }\end{array}$ & -.112 & .072 & $\begin{array}{r}- \\
.504 * \\
*\end{array}$ & -.181 & $\begin{array}{r}- \\
.483^{*} \\
*\end{array}$ \\
\hline $\mathrm{X}_{4}$ & $\begin{array}{l}\text { Total Work Participation } \\
\text { Rate of Muslim Population }\end{array}$ & $.523^{*}$ & -.024 & $.431^{-}$ & $.292 *$ & $.266^{*}$ \\
\hline $\mathrm{X}_{5}$ & $\begin{array}{l}\text { Main Work Participation } \\
\text { Rate of Muslim Population }\end{array}$ & $.439^{-}$ & $.451 *$ & $-.389 *$ & .107 & .126 \\
\hline $\mathrm{X}_{6}$ & $\begin{array}{l}\text { Marginal Work Participation } \\
\text { Rate of Muslim Population }\end{array}$ & -.205 & $\begin{array}{r}.933 * \\
*\end{array}$ & .268 & .072 & -.008 \\
\hline $\mathrm{X}_{7}$ & $\begin{array}{l}\text { Primary Work Participation } \\
\text { Rate of Muslim Population }\end{array}$ & -.231 & $379 * *$ & -.083 & -.428 & .093 \\
\hline $\mathrm{X}_{8}$ & $\begin{array}{l}\text { Secondary Work } \\
\text { Participation Rate of Muslim } \\
\text { Population }\end{array}$ & -.190 & -.008 & .223 & $.483^{* * *}$ & -.023 \\
\hline $\mathrm{X}_{9}$ & $\begin{array}{l}\text { Tertiary Work Participation } \\
\text { Rate of Muslim Population }\end{array}$ & -.218 & .093 & $.297 *$ & $.266^{*}$ & $\begin{array}{r}.379 * \\
*\end{array}$ \\
\hline $\mathrm{X}_{10}$ & $\begin{array}{l}\text { Sex Ratio of Muslim } \\
\text { Population }\end{array}$ & -.160 & -.023 & -.097 & $.316^{* *}$ & .023 \\
\hline $\mathrm{X}_{11}$ & $\begin{array}{l}\text { Ratio of Muslim Population } \\
\text { to Total Population }\end{array}$ & .268 & .126. & -.160 & .107 & -.161 \\
\hline $\mathrm{X}_{12}$ & $\begin{array}{l}\text { Per cent of Youth Population } \\
\text { among the Muslims }\end{array}$ & $\begin{array}{r}- \\
.480 * \\
*\end{array}$ & .023 & $\begin{array}{r}- \\
.569 * \\
*\end{array}$ & .072 & .081 \\
\hline
\end{tabular}

**Significance at 1 Per cent Level

* Significance at 5 Per cent Level

variables of educational status and that of socio-economic development of muslims. A simple association between educational status with socio-economic development have been computed and listed with the assumption that linear relationship existed in all the cases. The results are shown in the table. 3 . It was found that out of all the variables, the coefficients of correlation of three variables recorded a highly significant relationship with $\mathrm{Y}_{1}$. One among them, $\mathrm{X}_{4}$ is satisfying 95 percent level of confidence and bore direct relationship. However, $\mathrm{X}_{5}$ and $\mathrm{X}_{12}$ were found to be significant at 99 percent level of confidence with negative and positive relationships respectively. Out of the all selected variable only three variables bore significant relationship with $\mathrm{Y}_{2}$. Among them $\mathrm{X}_{5}$ was significant at 95 per cent level of confidence and the other two were found significant at 99 percent level of confidence and they all bore positive relationship. 
For the dependent variable $\mathrm{Y}_{3}$ six independent variables $\left(\mathrm{X}_{2}, \mathrm{X}_{3}, \mathrm{X}_{4}, \mathrm{X}_{5}, \mathrm{X}_{9}\right.$ and $\left.\mathrm{X}_{12}\right)$ recorded significant relationship and except $X_{9}$, all of them were significant at 99 per cent level of confidence and bore indirect relationship. The above discussion led to conclude that the educational level below primary or primary literates does not have any relationship with either main work participation rate or marginal work participation rate. Out of the all selected variable only four variables namely $\mathrm{X}_{4}, \mathrm{X}_{8}, \mathrm{X}_{9}$ and $\mathrm{X}_{10}$ ) bore significant relationship with $Y_{4}$ and all of them are positively correlated. Leaving $X_{4}$ which was significant at 95 per cent level of significance all the other variables are found to be significant at 99 per cent level of significance. For the dependent variable $\mathrm{Y}_{5}$ five independent variables $\left(\mathrm{X}_{1}, \mathrm{X}_{2}, \mathrm{X}_{3}, \mathrm{X}_{4}\right.$ and $\left.\mathrm{X}_{9}\right)$ showed significant relationship. First three variables bore indirect relationship and rest of the two bore direct relationship. Leaving $X_{4}$ which was found to be significant at 95 per cent, rest of the four variables were satisfying 99 per cent level of confidence.

\section{Conclusion}

Thus, it can safely be said that the educational status of Muslims in India is not satisfactory and needs special attention. It is clear from the Tab 1 that more than half i.e., 53.95 per cent of the total population of the Muslims in India is illiterate with 17.48 per cent literate people just for the name sake only. Technical education or higher education is meager among the muslim population. From the results it is clear that more than eighty per cent of the total population belongs to Hindu community. Muslims accounts for 13.43 per cent of the total population, whereas, a little less than ten per cent of the total population is constituted by Christian, Sikh, Budhist, Jain and other religious communities. Literacy rate is highest ( 84.09 per cent) among the jains who only accounts for less than half per cent of the total population; Christian occupies the second position followed by Budhist, Sikh, Hindu and the last Muslims in this order. Primary literacy rate is highest among the muslims and secondary, technical and higher education lowest among the muslims. Apart from it male female literacy gap is also highest among the muslims. While analyzing the sex ratio, it is found that muslims lie that second last position they come only after Hindus; and Christians occupies the top most position as far as sex ratio is concerned. From the results (Tab:3) it is also clear that primary literates $\left(\mathrm{Y}_{2}\right)$ of muslims show significant relationship with $\mathrm{X}_{4}$ ( Total Work Participation Rate), $\mathrm{X}_{5}$ (Main Work Participation Rate) and Per cent of $\mathrm{X}_{12}$ (Youth population among Muslims). However, Technical and Non Technical Diploma Holders $\left(\mathrm{Y}_{3}\right)$ show significant relationship with Secondary Work Participation Rates $\left(\mathrm{X}_{8}\right)$ and Tertiary Work Participation Rate $\left(\mathrm{X}_{9}\right)$. Apart from it higher education show significant relationship with Female Literacy Rate $\left(\mathrm{X}_{3}\right)$ and Tertiary Work Participation Rate $\left(\mathrm{X}_{9}\right)$. Thus at the end it can be safely said that muslims are educationally most backward religious community and they need special attention

\section{REFERENCES}

[1]. Sachar Committee Report. (2006), Social Economic And Educational Status Of Muslim Community In India, Cabinet Secretariat, Government Of India, New Delhi

[2]. http://www.islamfortoday.com/syed07.htm

[3]. http://www.indiatogather.org/2007/aur/edu-muslimedu.htm

[4]. S.P. Katiyar, Techniques and Models of Rural Development through Universities, University News, 46(29), 2008, 13-16.

[5]. M. Dayal, Importance and Universalisation of Education: The Role of Media, University News, 46(28), 2008, 17-22.

[6]. Sachchidananda, The Harijan Elite, (Thomson Press (India) Limited, Haryana, 1977).

[7]. G.S. Gosal, Spatial Perspective on Literacy in India, Population Geography, 1, 1979, 41-67.

[8]. B.B. Mathur, Rural Literacy in Uttar Pradesh: A Spatial Analysis, The Geographer, 15,1988, 80-90.

[9]. N.L. Gupta, and S. Kothari, Female Literacy in Rajasthan 1961-1981, Population Geography, 12, 1990

[10]. R.S. Tripathi, Impact of Urbanisation on Literacy and Concentration of Non- Agricultural Workers in Rural Areas of Bunelkhand (U.P), Geographical Review of India, 55, 1993, 78-82.

[11]. M. Siddique, The Geography of Literacy in Uttar Pradesh, Geographical Reveiw of India, 39, 1977, $374-388$.

[12]. A. Singh, Agricultural Population in the Urban Centers of Varanasi City Region- A Geographical Analysis, National Geographical Journal of India, 32, 1986, 40-48.

[13]. P Acharya, Problems of Weaker Section of the Rural Community, ICSSR Research Abstract Quarterly, 13, 1984, 29-40.

[14]. M. Raza, andY.P. Aggarwal, Inequalities in the Levels of Literacy in India, In: The Levels of Literacy in India, in M. Shafi,. And R. Raza, (Eds), Spectrum of modern geography, ( New Delhi: Concept Publications, 1986) 193-225.

[15]. S.C. Nuna, Regional Disparities in Educational Development- Policy and Planning Implications, Paper presented at National Seminar on Regional Disparities in Educational Development, NIEPA,1989, New Delhi.

[16]. M. Pacione, The Geography of Educational Disadvantage in Glassgow, Applied Geography, 17, 1997. 169-175.

[17]. A.B.G. Tilak, Inter-State Disparities in Educational Development, Eastern Economy, 73, 1979, $140-146$.

[18]. U.B. Redy, Regional Disparities in Educational Development in India: An Inter-State Analysis, Geographical Review of India, 58, $1985,22-27$.

[19]. A.N. Zaidi, Educational Planning and Regional Disparities in Tilak. J.B.G. (Ed) Education and Regional Development, (Yatah Publication, 1986) 170-182.

[20]. G.S. Mehta, Educational Equality: Reality or Myth, Indian Journal of Regional Science, 12, 1990, 87-93.

[21]. K. Saradamoni, Education or Leveler A Probe into Kerela's Experience, in K.R.G. Nair, (Ed) Regional Disparities in India, (New Delhi, 1981) 121-13.

[22]. T.R. Dash, Regional Inequalities in Educational Development in Orrisa, Indian Journal of Regional Science, 25, 1993, $19-29$.

[23]. L. Mc. Doughal, Gender Gap in Literacy in Uttar Pradesh, Questions For Decentralization Educational Planning, Economic and Political Weekly, 30, 2000, 1649-1651. 
[24]. F.A. Siddiqui and Y. Naseer, Educational Development and Structure of Work participation in Western Uttar Pradesh, Population Geography, 26 (1 \& 2), 2004, pp. 25-36.

[25]. R. S. Dube, and P.R. Mishra, Level of Education- A Versatile Indicator of Regional Development, Geographical Review of India, 43, 1981, 278-285.

[26]. M.D Chaudhary, and K.P.G .Nair, Education and Regional Development in India, Indian Journal of Regional Science, 13, 1981, 170-180.

[27]. C.P. Singh, Literacy in the Rural Population of Meerut District, Geographical Observer, 15, 1979, $32-37$.

[28]. Census of India , Tab C-9, 2001

[29]. http://www.knowledgecommission.gov.in/recommendations/school.asp 